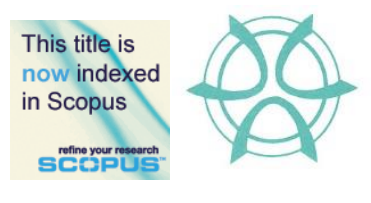

PLANNING MALAYSIA:

Journal of the Malaysian Institute of Planners

VOLUME 17 ISSUE 2 (2019), Page 334 - 342

\title{
AN ASSESSMENT ON EARLY WARNING SYSTEM: INITIAL SURVEY ANALYSIS
}

\author{
Mohd Ramzi Mohd Hussain', Noor Suzilawati Rabe' ${ }^{2}$ Ismawi Zen', \\ Izawati Tukiman $^{4}$, Rahsidi Sabri Muda ${ }^{5}, \&$ Ahmad Fadhli Mamat ${ }^{6}$ \\ ${ }^{1,2,4}$ Kulliyyah of Architecture and Environmental Design \\ INTERNATIONAL ISLAMIC UNIVERSITY MALAYSIA \\ ${ }^{3}$ AL MADINAH INTERNATIONAL UNIVERSITY \\ ${ }^{5,6}$ Tenaga National Berhad Research \\ TENAGA NASIONAL BERHAD
}

\begin{abstract}
In Cameron Highland, Lembah Bertam area and further downstream villages in Susu Dam area are prone and vulnerable to the highest occurrence of floods especially during monsoon season. Thus, Early Warning System (EWS) were set up to avoid or to reduce the impact of natural hazard turns disasters such as floods, landslides and storms with the aim to reduce the vulnerability and disaster risks that signifies the effectiveness of EWS in the realisation of affected community. To test the awareness and preparedness of community in the selected area, a questionnaire survey was employed as the data collection method. The questionnaire survey was conducted before the direct engagement on the EWS information with the community. Using the mixed sampling method of cluster random sampling, a total of 800 respondents from 11 villages, and 5 main ethnicity groups were involved in the survey. From the result, there was a positive relationship showing that respondents who claimed they knew about the EWS from information signage were those from the older age category and earning higher monthly income. On the other hand, there is a negative relationship between respondents' age and monthly income against other sources that indicates respondents who claimed they knew about the EWS from other sources were those in the younger age category and have low monthly income.
\end{abstract}

Keywords: early warning system; dam, hazard, Cameron Highland 
PLANNING MALAYSIA

Journal of the Malaysia Institute of Planners (2019)

\section{INTRODUCTION}

Overall, there are 74 dams in Malaysia, which consist of various types and functions. Dams in Malaysia are owned and operated by different agencies such as the Department of Irrigation and Drainage, Water Supply Department, energy supply company (such as TNB), State Government and other agencies according to their respective needs and responsibilities.

Apart from other functions, provision of dams is also essential for the nation's infrastructure to provide for renewable energy of hydropower electricity. Hydropower is the only renewable energy technology that is presently commercially viable on a larger scale. It has four major advantages, namely it is renewable, it produces negligible amounts of greenhouse gases, it is the least costly way of storing large amounts of electricity, and it can easily adjust the amount of electricity produced to the amount demanded by consumers.

However, construction and dam development posed potential hazard to communities, the environment and property, often well beyond their locations. Among the impacts of dam include dam failure that could lead to flood event that cause potential flooding impacts to the community and assets (vulnerability). Thus, this paper explores the community knowledge on the dam failure and flood early warning system at Lembah Bertam and Susu Dam area.

\section{BACKGROUND OF THE STUDY}

Hazard is defined as phenomena that poses a threat to people, structures or economic assets and which may cause a disaster (UN-SPIDER, 2015). Disaster could be categorised either man-made or naturally occurring, while vulnerability is the extent to which a community are exposed to loss or damage that indirectly influence their perceptions and willingness to act(Jones et al, 2014).

As recorded in the Global Risks report (World Economic Forum, 2016), the world we are living in is facing issues of climate change, social instability, unmanageable inflation, large scale involuntary migration, biodiversity loss, terrorism, and so forth. It is forecasted that countries like in Asia are likely to experience major natural catastrophes with extreme weather events (World Economic Forum, 2016). Asia accounts for $70 \%$ of natural disasters in the world (ADB, 2012). The main reason for this is the fact that Asia Pacific lies within Pacific Ring of Fire, which accounts for $90 \%$ world's earthquakes and $70 \%$ of world's volcanoes (Jha \& Brecht, 2011).

Malaysia is geographically located outside the Pacific Ring of Fire. Therefore, it is relatively free from certain severe crises found in neighbouring countries. However, as shown in Figure 1, Malaysia is vulnerable to natural hazards including floods, forest fires, tsunami, cyclonic storms, landslides, epidemics, and haze. 
Mohd Ramzi M.H., Noor Suzilawati R., Ismawi Z., Izawati T., Rahsidi S.M., \& Ahmad Fadhli M. An Assessment on Early Warning System: Initial Survey Analysis
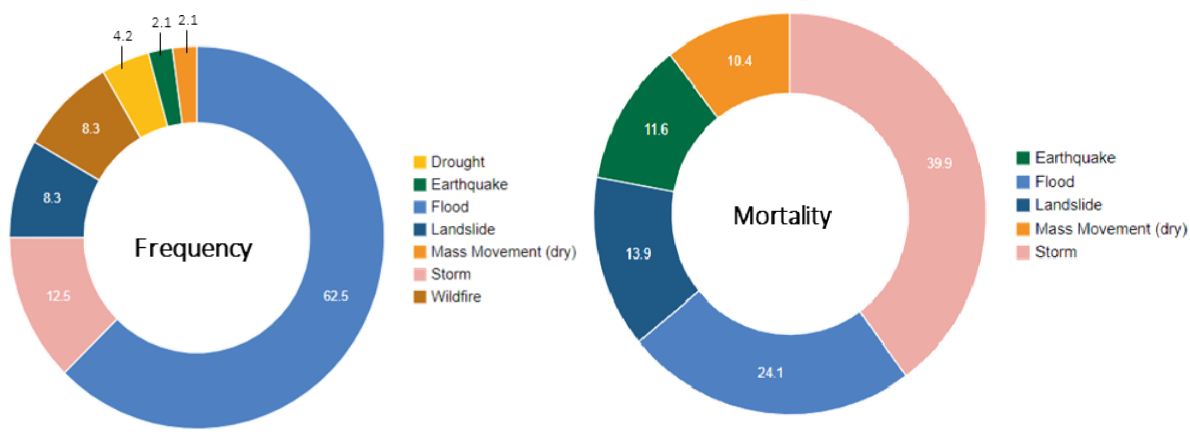

Figure 1 Disaster and risk profile of Malaysia Source: EM-DAT (Feb. 2015)

Disaster is a serious disruption of the functioning of a community or a society causing widespread human, material, economic or environmental losses, which exceed the ability of the affected community or society to cope, using its own resources (UNISDR, 2004). A disaster occurrence happens when an impact of hazard affected a vulnerable population that causes damage, disruption and casualties. Therefore, it is important for the Early Warning System (EWS) to be set up to avoid or reduce the impact of natural hazard turn disasters such as floods, landslides and storms with the aim to reduce the vulnerability and disaster risks that signify the effectiveness of EWS in the realisation of affected community. The official United Nations International Strategy for Disaster Reduction (UNISDR, 2009) defines the Disaster Risk Management as:

"The systematic process of using administrative directives, organisations, and operational skills and capacities to implement strategies, policies and improved coping capacities in order to lessen the adverse impacts of hazards and the possibility of disaster."

The Malaysian government has adopted UN World Conference global plan for natural disaster risk reduction, the Hyogo Frameworks for Actions (20052015) and Sendai Framework (2015-2030). Malaysia also undertakes initiatives to mainstream disaster risk management and reduction to be in line with the 11th Malaysia Plan, the nation's primary development plan. Disaster management has consistently been a focus of Malaysia's development policy. Malaysia's National Platform for DRR was formalised in 2013, which involves various stakeholders from different government agencies, as well as collaboration with the private sector. This is reflected through the amount of resources invested to minimise risk factors and facilitate sustainable development, and one of the initiatives is the implementation of the Early Warning System (EWS) to the affected community.

EWS is the representation of a set of capacities needed to generate and disseminate timely with meaningful warning information that enables at-risk 
PLANNING MALAYSIA

Journal of the Malaysia Institute of Planners (2019)

individuals, communities and organisations to prepare and act accordingly, and in sufficient time to reduce harm or loss. According to Mohd Hussain et al. (2018), EWS can be categorised into community managed EWS and community based EWS. A community managed EWS refers to the system managed by community but they are not completely involved in the establishment of the system. Whereas, community based EWS is a system developed, operated and maintained by the community itself. While developing the system, the community would explore external support from different individuals, communities, organisations and institutions. Thus it can be concluded that it is necessary that the community develops and maintains close coordination and links with the stakeholders.

As EWS tends to focus on warning and monitoring on hazards and threats only, hazards and vulnerability should be assessed together to reduce risks. A community which is highly exposed to hazard also experiences a high level of vulnerability and needs a more heads-up warning.

\section{STUDY METHODOLOGY}

The initial survey questionnaire was designed to elicit the perceptions of the community before EWS implementation in the settlements. The survey was conducted on a one-to-one interview basis with a total survey population of 800 respondents who reside in the Sultan Abu Bakar (SAB) Dam and Susu Dam areas.

This research employed the method of probability sampling in which it gives an equal opportunity to the population to be included in a sample. Brown (1947) elaborated that a probability or random sampling has the greatest freedom bias but may represent the most costly sample in terms of time and energy for a given level of sampling error. In selecting samples from the targeted sampling, cluster sampling was chosen as it assumed as the best sampling technique for this research. Cluster sampling is advantageous for those researchers whose subjects are fragmented over large geographical areas as it saves time and money (Davis, 2005). Overall, the number of respondents from each village represented $30 \%$ of the total village population.

The data retrieved from the questionnaire was analysed using IBM SPSS Statistics Version 23. The first phase of questionnaire survey was done before the community engagement programme with the population. This intended to gauge the response from respondents that could reflect their nature of understanding, awareness and preparedness of the community in Cameron Highlands before the EWS was installed.

The questionnaire survey for this research was divided into three main sections which consisted of Section A: demographic information of the respondents, Section B: information on experience before the implementation of EWS, and Section C: information on experience during the installation of EWS. 
Mohd Ramzi M.H., Noor Suzilawati R., Ismawi Z., Izawati T., Rahsidi S.M., \& Ahmad Fadhli M.

An Assessment on Early Warning System: Initial Survey Analysis

\section{RESULT OF INTIAL SURVEY AND ANALYSIS}

This section discusses on result of primary data collection in the study area. The discussion starts with analysis on background of respondents followed with descriptive analysis on their knowledge on EWS. Result on respondents' profile is presented in Table 1 below. Based on ethnicity distribution according to village in Table 1 above, the highest percentage for Semai ethnic group with $98.7 \%$ were respondents from $\mathrm{Kg}$. Renglas, followed with $96.5 \%$ from $\mathrm{Kg}$. Leryar and $93.4 \%$ from Kg. Teji. Meanwhile, for Temiar ethnic group, the highest percentage with 44.4\% were respondents from Pos Telanuk.

Table 1 Ethnicity distribution according to village

\begin{tabular}{|c|c|c|c|c|c|c|c|c|c|c|c|c|c|c|}
\hline \multirow{3}{*}{ Village } & \multicolumn{14}{|c|}{ Ethnicity } \\
\hline & \multicolumn{2}{|c|}{ Semai } & \multicolumn{2}{|c|}{ Temiar } & \multicolumn{2}{|c|}{ Melayu } & \multicolumn{2}{|c|}{ Cina } & \multicolumn{2}{|c|}{ India } & \multicolumn{2}{|c|}{ Others } & \multicolumn{2}{|c|}{ Total } \\
\hline & $\mathrm{F}$ & $\%$ & $\mathrm{~F}$ & $\%$ & $\mathrm{~F}$ & $\%$ & $\mathrm{~F}$ & $\%$ & $\mathrm{~F}$ & $\%$ & $\mathrm{~F}$ & $\%$ & $\mathrm{~F}$ & $\%$ \\
\hline $\begin{array}{l}\text { Lembah } \\
\text { Bertam }\end{array}$ & 16 & 6.1 & 1 & 0.4 & 53 & 20.1 & 137 & 51.9 & 16 & 6.1 & 41 & 15.5 & 264 & 100 \\
\hline Sg. Tiang & 100 & 90.1 & 1 & 0.9 & 1 & 0.9 & 1 & 0.9 & 6 & 5.4 & 2 & 1.8 & 111 & 100 \\
\hline Mensun & 29 & 74.4 & 4 & 10.3 & 5 & 12.8 & 0 & 0.0 & 1 & 2.6 & 0 & 0.0 & 39 & 100 \\
\hline Leryar & 83 & 96.5 & 0 & 0.0 & 1 & 1.2 & 0 & 0.0 & 1 & 1.2 & 1 & 1.2 & 86 & 100 \\
\hline Teji & 57 & 93.4 & 3 & 4.9 & 1 & 1.6 & 0 & 0.0 & 0 & 0.0 & 0 & 0.0 & 61 & 100 \\
\hline Bako & 10 & 90.9 & 0 & 0.0 & 1 & 9.1 & 0 & 0.0 & 0 & 0.0 & 0 & 0.0 & 11 & 100 \\
\hline Pos Te & 5 & 55.6 & 4 & 44.4 & 0 & 0.0 & 0 & 0.0 & 0 & 0.0 & 0 & 0.0 & 9 & 100 \\
\hline Susu & 78 & 100 & 0 & 0.0 & 0 & 0.0 & 0 & 0.0 & 0 & 0.0 & 0 & 0.0 & 78 & 100 \\
\hline Habu & 31 & 88.6 & 2 & 5.7 & 2 & 5.7 & 0 & 0.0 & 0 & 0.0 & 0 & 0.0 & 35 & 100 \\
\hline Senangkar & 27 & 90 & 3 & 10 & 0 & 0.0 & 0 & 0.0 & 0 & 0.0 & 0 & 0.0 & 30 & 100 \\
\hline Renglas & 75 & 98.7 & 1 & 1.3 & 0 & 0.0 & 0 & 0.0 & 0 & 0.0 & 0 & 0.0 & 76 & 100 \\
\hline Total & 511 & 63.9 & 19 & 2.4 & 64 & 8.0 & 138 & 17.2 & 24 & 3.0 & 44 & 5.5 & 800 & 100 \\
\hline
\end{tabular}

As shown in Table 2, from the total respondents from $\mathrm{Kg}$. Bako, $54.5 \%$ of them claimed they never attended school while the remaining of $45.5 \%$ of them had attended at least secondary education level. Meanwhile, $54.1 \%$ of total respondents from $\mathrm{Kg}$. Teji claimed they have attended primary school and $34.4 \%$ attended secondary school. In addition, from the total 18 respondents who claimed they have certificate or college qualification, 5.7\% of them were from $\mathrm{Kg}$. Habu, 5.4\% from Kg. Sg. Tiang and 3.1\% from Lembah Bertam. However, for respondents from Lembah Bertam, none of the respondents from other villages had obtained university level education. 
Table 2 Respondents' educational level distribution according to village

\begin{tabular}{|c|c|c|c|c|c|c|c|c|c|c|c|c|}
\hline \multirow{3}{*}{ Village } & \multicolumn{12}{|c|}{ Educational level } \\
\hline & \multicolumn{2}{|c|}{$\begin{array}{l}\text { Never } \\
\text { attended } \\
\text { school }\end{array}$} & \multicolumn{2}{|c|}{$\begin{array}{c}\text { Primary } \\
\text { school }\end{array}$} & \multicolumn{2}{|c|}{$\begin{array}{c}\text { Secondary } \\
\text { school }\end{array}$} & \multicolumn{2}{|c|}{$\begin{array}{l}\text { Certificate- } \\
\text { college/ } \\
\text { institute }\end{array}$} & \multicolumn{2}{|c|}{ University } & \multicolumn{2}{|c|}{ Total } \\
\hline & $\mathrm{F}$ & $\%$ & $\mathrm{~F}$ & $\%$ & $\mathrm{~F}$ & $\%$ & $\mathrm{~F}$ & $\%$ & $\mathrm{~F}$ & $\%$ & $\mathrm{~F}$ & $\%$ \\
\hline Lembah Bertam & 41 & 15.6 & 75 & 28.6 & 129 & 49.2 & 8 & 3.1 & 9 & 3.4 & 262 & 100 \\
\hline Sg. Tiang & 27 & 24.3 & 34 & 30.6 & 44 & 39.6 & 6 & 5.4 & 0 & 0.0 & 111 & 100 \\
\hline Mensun & 8 & 20.5 & 19 & 48.7 & 11 & 28.2 & 1 & 2.6 & 0 & 0.0 & 39 & 100 \\
\hline Leryar & 7 & 8.1 & 38 & 44.2 & 41 & 47.7 & 0 & 0.0 & 0 & 0.0 & 86 & 100 \\
\hline Teji & 7 & 11.5 & 33 & 54.1 & 21 & 34.4 & 0 & 0.0 & 0 & 0.0 & 61 & 100 \\
\hline Bako & 6 & 54.5 & 0 & 0.0 & 5 & 45.5 & 0 & 0.0 & 0 & 0.0 & 11 & 100 \\
\hline Pos Telanuk & 0 & 0.0 & 3 & 33.3 & 6 & 66.7 & 0 & 0.0 & 0 & 0.0 & 9 & 100 \\
\hline Susu & 17 & 21.8 & 16 & 20.5 & 44 & 56.4 & 1 & 1.3 & 0 & 0.0 & 78 & 100 \\
\hline Habu & 6 & 17.1 & 6 & 17.1 & 21 & 60 & 2 & 5.7 & 0 & 0.0 & 35 & 100 \\
\hline Senangkar & 3 & 10 & 11 & 36.7 & 16 & 53.3 & 0 & 0.0 & 0 & 0.0 & 30 & 100 \\
\hline Renglas & 8 & 10.5 & 20 & 26.3 & 48 & 63.2 & 0 & 0.0 & 0 & 0.0 & 76 & 100 \\
\hline Total & 130 & 16.3 & 255 & 32 & 386 & 48.4 & 18 & 2.3 & 9 & 1.1 & $798 *$ & 100 \\
\hline
\end{tabular}

Note: $* 2$ respondents did not answer the question.

As shown in Table 3,84.8\% of the total respondents claimed they had knowledge on the EWS, while only $15.2 \%$ claimed otherwise. A cross tabulation as shown in Table 4 recorded the responses between the source of information how respondents knew about EWS with their knowledge on EWS.

Table 3 Respondents' knowledge on EWS

\begin{tabular}{|l|c|c|}
\hline \multicolumn{1}{|c|}{ Respond } & Frequency $(\mathrm{F})$ & Percentage (\%) \\
\hline No & 122 & 15.2 \\
\hline Yes & 678 & 84.8 \\
\hline Total & 800 & 100 \\
\hline
\end{tabular}

In Table 4 below, $22.6 \%$ of respondents who they knew about EWS claimed they got the information from 'information signage', $4.3 \%$ from television and $66.9 \%$ from other types of information sources. However, there were also respondents who claimed they did not know about the EWS but answered they heard it from the internet $(99.4 \%)$, radio (98.4\%) and newspaper $(98.3 \%)$

Table 4 Respondents' source of EWS information

\begin{tabular}{|l|c|c|c|c|c|c|}
\hline \multirow{2}{*}{ Source of information } & \multicolumn{2}{|c|}{ No } & \multicolumn{2}{c|}{ Yes } & \multicolumn{2}{c|}{ Total } \\
\cline { 2 - 7 } & $\mathrm{F}$ & $\%$ & $\mathrm{~F}$ & $\%$ & $\mathrm{~F}$ & $\%$ \\
\hline $\begin{array}{l}\text { Short Message System } \\
\text { (SMS) }\end{array}$ & 783 & 97.9 & 17 & 2.1 & 800 & 100 \\
\hline Television & 766 & 95.8 & 34 & 4.3 & 800 & 100 \\
\hline Radio & 787 & 98.4 & 13 & 1.6 & 800 & 100 \\
\hline Newspaper & 786 & 98.3 & 14 & 1.8 & 800 & 100 \\
\hline
\end{tabular}


Mohd Ramzi M.H., Noor Suzilawati R., Ismawi Z., Izawati T., Rahsidi S.M., \& Ahmad Fadhli M. An Assessment on Early Warning System: Initial Survey Analysis

\begin{tabular}{|l|c|c|c|c|c|c|}
\hline Internet & 795 & 99.4 & 5 & 0.6 & 800 & 100 \\
\hline Information signage & 619 & 77.4 & 181 & 22.6 & 800 & 100 \\
\hline Others & 265 & 33.1 & 535 & 66.9 & 800 & 100 \\
\hline
\end{tabular}

As shown in Table 5, since the critical value of respondents' education level with television as source of information was less than 0.05 , thus $\mathrm{H}_{0}$ that stated no relationship between the variables can be rejected. In addition, information signage against education level (0.000), ethnicity (0.000) and village where respondents lived (0.016) as well as other sources of information with education level (0.001), ethnicity (0.000) and village where respondents lived $(0.000)$ were less than 0.05 , therefore the $\mathrm{H}_{0}$ can be rejected. In other words, education level, ethnicity and village did have an influence on the sources from where respondents received information related to EWS.

Table 5 Chi-square Test between source of information on EWS with educational level, ethnicity and village

\begin{tabular}{|l|c|c|c|c|c|c|c|c|c|}
\hline \multirow{2}{*}{$\begin{array}{l}\text { Source of } \\
\text { information }\end{array}$} & \multicolumn{3}{|c|}{ Education level } & \multicolumn{3}{c|}{ Ethnicity } & \multicolumn{3}{c|}{ Village } \\
\cline { 2 - 10 } & $\%$ & CV & Value & $\%$ & CV & Value & $\%$ & CV & Value \\
\hline $\begin{array}{l}\text { Short Message } \\
\text { System (SMS) }\end{array}$ & 30 & .680 & 2.305 & 41.7 & .747 & 2.696 & 45.5 & .443 & 9.972 \\
\hline Television & $\mathbf{2 0}$ & $\mathbf{. 0 0 1}$ & $\mathbf{1 9 . 9 3 6}$ & 33 & .195 & 7.365 & 45.5 & .000 & 63.958 \\
\hline Radio & 40 & .085 & 8.197 & 41.7 & .594 & 3.697 & $\mathbf{5 0}$ & $\mathbf{. 0 0 7}$ & $\mathbf{1 6 . 9 2 8}$ \\
\hline Newspaper & 40 & .428 & 3.843 & $\mathbf{4 1 . 7}$ & $\mathbf{. 0 4 5}$ & $\mathbf{1 1 . 3 2 0}$ & 50 & .367 & 10.876 \\
\hline Internet & $\mathbf{5 0}$ & $\mathbf{. 0 0 2}$ & $\mathbf{1 7 . 1 8 8}$ & $\mathbf{5 0}$ & $\mathbf{. 0 0 0}$ & $\mathbf{3 4 . 0 0 6}$ & $\mathbf{5 0}$ & $\mathbf{. 0 0 0}$ & $\mathbf{7 1 . 0 3 1}$ \\
\hline $\begin{array}{l}\text { Information } \\
\text { signage }\end{array}$ & $\mathbf{2 0}$ & $\mathbf{. 0 0 0}$ & $\mathbf{2 1 . 8 6 5}$ & $\mathbf{8 . 3}$ & $\mathbf{. 0 0 0}$ & $\mathbf{4 8 . 6 0 4}$ & $\mathbf{9 . 1}$ & $\mathbf{. 0 1 6}$ & $\mathbf{2 1 . 9 0 9}$ \\
\hline Others & $\mathbf{1 0}$ & $\mathbf{. 0 0 1}$ & $\mathbf{1 7 . 7 5 1}$ & $\mathbf{0 . 0}$ & $\mathbf{. 0 0 0}$ & $\mathbf{4 9 . 6 4 5}$ & $\mathbf{9 . 1}$ & $\mathbf{. 0 0 0}$ & $\mathbf{5 2 . 4 0 2}$ \\
\hline
\end{tabular}

Note: $\%=\%$ cell with count less than $5, \mathrm{CV}=$ Critical value

Another test using the Spearman rho test (Table 6) was also conducted to test the sources of information on EWS with respondents' age, duration of stay and households monthly income. The results show that the significant values of respondents' age against information signage $(0.005)$ and other sources $(0.010)$, respondents' monthly income against information signage $(0.000)$ and other sources $(0.000)$ were less than 0.05 , hence, the null hypothesis can be rejected. In addition, the results also show that there was a positive and low relationship between respondents' age $\left(0.100^{* *}\right)$ and respondents' monthly income $\left(0.124^{* *}\right)$ against their answer on information signage. The positive relationship shows that respondents who claimed they knew about the EWS from information signage were those in older age category and earning higher monthly income. Meanwhile, the negative relationship between respondents' age (-0.091**) and respondents' monthly income $(-0.179 * *)$ against other sources indicates that respondents who claimed they knew about the EWS from other sources were those in younger age category and have low monthly income. 
PLANNING MALAYSIA

Journal of the Malaysia Institute of Planners (2019)

Table 6 Spearman Rho test between source of information on EWS with age, duration of stay and household income

\begin{tabular}{|l|c|c|c|c|c|c|}
\hline \multirow{2}{*}{ Source of information } & \multicolumn{2}{|c|}{ Age } & \multicolumn{2}{c|}{ Duration of stay } & \multicolumn{2}{c|}{$\begin{array}{c}\text { Households month } \\
\text { income (RM) }\end{array}$} \\
\cline { 2 - 7 } & CC & $\begin{array}{c}\text { Sig. } \\
\text { Value }\end{array}$ & CC & $\begin{array}{c}\text { Sig. } \\
\text { Value }\end{array}$ & CC & $\begin{array}{c}\text { Sig. } \\
\text { Value }\end{array}$ \\
\hline $\begin{array}{l}\text { Short Message System } \\
\text { (SMS) }\end{array}$ & .021 & .550 & -.041 & .246 & .025 & .481 \\
\hline Television & .053 & .133 & -.013 & .713 & .031 & .383 \\
\hline Radio & .008 & .829 & -.056 & .114 & .062 & .080 \\
\hline Newspaper & -.008 & .826 & .001 & .986 & .038 & .281 \\
\hline Internet & -.012 & .740 & -.028 & .427 & .052 & .140 \\
\hline Information signage & $\mathbf{. 1 0 0} * *$ & $\mathbf{. 0 0 5}$ & .025 & .479 & $\mathbf{. 1 2 4} * *$ & $\mathbf{. 0 0 0}$ \\
\hline Others &.$- .091 * *$ & $\mathbf{. 0 1 0}$ & .064 & .070 & $\mathbf{- . 1 7 9 * *}$ & $\mathbf{. 0 0 0}$ \\
\hline
\end{tabular}

$\mathrm{CC}=$ Coefficient correlation, Sig.value $=$ Significant Value

$* \& * *$ Correlation is significant at the 0.05 level (2-tailed)

\section{FINDINGS AND CONCLUSION}

Data collection was conducted to gauge respondents' awareness and knowledge on the EWS. The target population was focused on Sultan Abu Bakar Dam and Susu Dam areas. The survey results indicated that only $15.2 \%$ claimed they did not know about the EWS. Meanwhile, respondents who knew about the EWS claimed they received the information mainly from 'information signage' $(22.6 \%)$. In addition, Chi-square test result showed that respondents' education level, ethnicity and village did influence on sources from where respondents received the information related to EWS. On the other hand, Spearman rho test indicated there was a positive and low relationship between respondents' age and their monthly income against their answer on information signage. The positive relationship shows that respondents who claimed they knew about the EWS from information signage were those in older age category and earning higher monthly income. In contrast, the negative relationship between respondents' age and monthly income against other sources indicate that respondents who claimed they knew about the EWS from other sources were those in younger age category and have low monthly income. This shows that respective agencies and local authority should use various medium of information to disseminate awareness and knowledge on EWS to the community that able to cater all categories of community's age, education level and level of income.

Hence, variation in methods used by local agencies and authorities in ensuring the information on EWS and disaster awareness are important in catering the differences in demography and socio-economic background of the respondents. Among all methods, one to one or direct engagement of local authority and agencies with the community is significant to increase their understanding and awareness. In addition, the engagement also should be frequent to ensure the community are well prepared in facing the disaster. 
Mohd Ramzi M.H., Noor Suzilawati R., Ismawi Z., Izawati T., Rahsidi S.M., \& Ahmad Fadhli M.

An Assessment on Early Warning System: Initial Survey Analysis

\section{ACKNOWLEDGEMENTS}

This study was conducted under a consultancy project in collaboration with Tenaga Nasional Berhad Research (TNBR).

\section{REFERENCES}

Asian Development Bank [ADB] (2012). Fast facts for disaster risk management in Asian cities. Manila: Author.

Brown, G. H. (1947). A comparison of sampling methods. Journal of Marketing, 6, 331337.

Davis, D. (2005). Business research for decision making. Pacific Grove, CA: Brooks/Cole Publishing Company.

EM-DAT (Feb. 2015) - The OFDA/CRED - International Disaster Database http://www.emdat.be - Université catholique de Louvain Brussels - Belgium

Jha, A., \& Brecht, H. (2011). An eye on East Asia and Pacific: Building Urban Resilience in East Asia. Washington DC: World Bank.

Jones, R.N., et al. (201 4). Foundations for decision making. In Barros, V.R. et al. (eds) (2014). Climate Change 2014: Impacts, Adaptation, and Vulnerability.Part A: Global and Sectoral Aspects. Contribution of Working Group II to the Fifth Assessment Report of the Intergovernmental Panel on Climate Change. Cambridge, United Kingdom and New York: Cambridge University Press.

Mohd Hussain, M. R., Zen, I., Muda, R. S., Thiruchelvam, S., Tukiman, I., \& Ahmad Shazili, A. N. (2018). Community Awareness on The Implementation of Early Warning System at Tenaga Nasional Berhad Sultan Abu Bakar Hydroelectric Scheme, Lembah Bertam, Cameron Highland. Planning Malaysia, 16(1), 155-162.

UN-SPIDER. (2015). Disaster risk management. Retrieved June 27, 2019, from http://www.un-spider.org/risks-and-disasters/disaster-risk-management

UNISDR. (2004). On-line conference: Priority areas to implement disaster risk reduction. Retrieved June 27, 2019, from https://www.unisdr.org/2004/wcdrdialogue/terminology.htm

UNISDR. (2009). UNISDR terminology on disaster risk reduction. Available at www.preventionweb.net

World Economic Forum (2016). Global risks 2016. Availaible at www.weforum.org

Received: $20^{\text {th }}$ July 2019. Accepted: $2^{\text {nd }}$ August 2019 